\title{
THE RELATION BETWEEN SOME FORMS OF NON-GONOCOCCAL URETHRITIS, LYMPHOGRANULOMA INGUINALE, TRACHOMA, AND INCLUSION BLENNORRHEA
}

\section{CRITICAL REVIEW}

By L. W. HARRISON, D.S.O., M.B., Ch.B., F.R.C.P.E., and W. WORMS, M.D.(Berlin).

A FEW isolated facts have stimulated the writing of this review. The chief are :-

(I) The finding by some workers that an antigen made from the urethral discharge of patients with "Waelsch urethritis " acts like Frei antigen in cases of lymphogranuloma inguinale.

(2) The discovery by Gay-Prieto, Findlay, Miyagawa and others of the bodies now believed to be the virus of lymphogranuloma inguinale.

(3) The previous discovery by many workers of somewhat similar inclusion bodies in cases of "Waelsch urethritis," inclusion blennorrhœa, trachoma and some other diseases.

It appeared to us worth while to search the literature to discover, if possible, any further evidence indicating a relationship between the above diseases.

Before discussing the papers which have been studied for this review it seems necessary to state the criteria on which a diagnosis of Waelsch urethritis has been founded because they appear to have differed according to the importance attached to the urethroscopic appearances.

In I90I, Waelsch described a rare form of nongonorrhœal urethritis which he believed to be a clinical entity. It was characterised principally by its relatively long incubation period, the slightness of its subjective and objective symptoms and its almost complete resistance to treatment. The incubation period varied from 
five to sixteen days, and the condition appeared to be chronic from the first; in some cases there might be slight itching of the urethra, and the discharge was usually slight, mostly grey or yellowish, sometimes rather tough, sometimes more liquid and slimy with purulent streaks. The urine was usually clear, with heavy threads and shreds, or in some cases might be hazy or turbid. No gonococci were ever found, and other organisms were either completely absent or only scanty. The condition continued unchanged except for slight remissions and exacerbations, defying all treatment, for years. Although this description might appear to fit a number of different kinds of urethritis, other authors supported Waelsch in considering that the cases he had described were of a distinct type, and Urethritis Typus Waelsch became established as a clinical entity. Probably most readers with much experience of urethritis have occasionally had cases which corresponded closely in characteristics to the above description.

Apparently no report on the urethroscopic appearance of this urethritis was published until Glingar (I9I4) described in II cases of the kind a reddened mucous membrane with diffuse or circumscribed soft infiltrates mostly in the fore part of the urethra, and in the infiltrates millet-seed to pin-head sized, grey or greyish yellow, somewhat translucent nodules standing out from the surface like the nodules in trachoma. Later, as mentioned by Ross in the April number of this Journal, Glingar (I932) named the condition Urethritis cystica erythematosa and distinguished it from what he called Oberländer's Urethritis indurativa cystica by the redness of the mucous membrane and the absence of any hard infiltrate. He described the discharge as being watery or rather like libidinous discharge but distinguished from this by its slight viscosity and in being yellow-grey and more creamy.

In I9I6, Waelsch reviewed his further experience of this form of urethritis and stated that in the last ten years he had seen $5 \mathrm{I}$ cases. He repeated his description of the symptoms and added that he had seen urethroscopic appearances similar to those described by Glingar in 3 old-standing cases, but he did not regard them as characteristic. He thought their presence might support a diagnosis of Waelsch urethritis but their absence should 
not militate against one. In all his other cases he had found only redness and swelling of the mucous membrane and varying involvement of crypts of Morgagni. He had seen some cases develop posterior urethritis and prostatitis. Scherber in his monograph on non-gonorrhœal urethritis in Arzt and Zieler's text-book mentioned that in twelve years he had seen II cases of Waelsch urethritis of which 5 had recovered. Except for mention of some nodular formation in the mucous membrane of I case he did not seem to confirm or otherwise Glingar's findings. Frühwald's article in Jadassohn's “ Handbuch der Haut und Geschlechtkrankheiten," in repeating the descriptions of Waelsch urethritis and Glingar's findings, mentioned that Reichmann had always found hyperæmia with granulations in the mucous membrane in cases of Waelsch urethritis, but in his own II cases of this kind the author does not seem to have been impressed by the endoscopic appearances. Similarly, in a number of the papers reviewed below endoscopic findings are not mentioned, and it appears as if most authors had relied for their diagnosis mainly on the criteria originally set out by Waelsch.

To one of us (L. W. H.) this scanty mention of endoscopic appearances in Waelsch urethritis is surprising, considering that in most of the cases which he has seen with characters corresponding closely to the original description by Waelsch - chronic course, slight symptoms, rather scanty but glairy or slimy or muco-purulent discharge and non-response to treatment-the appearances of the anterior urethra under urethroscopy with air inflation have been striking, especially if the urethroscopy was performed from the meatal end towards the triangular ligament instead of in the opposite direction, the air inflation acting as the pilot which prevents the end of the cannula from pressing too hard on the mucous membrane. In a well-marked case of the kind under discussion the urethra when inflated and examined under slight $\left(\times 2 \frac{1}{2}\right)$ magnification may look as if paved in places with old-fashioned round cobble-stones, and out of the granules, which may look like half-boiled sagograins, it is often possible with the end of the cannula to force pus. Before the introduction of sulphonamide treatment the only effective method of dealing with this condition seemed to be to touch the majority of the 
granules with the point of a fine electric cautery, operated through the urethroscope whilst the air inflation was maintained. Whether the granular or nodular condition of the urethra which workers in this country often speak of as millet-seed or sago-grain urethritis is always present in Waelsch urethritis, or this condition is something different, cannot definitely be said, but the other clinical signs of sago-grain urethritis seem to correspond quite closely with Waelsch's description, and one of us always expects to find the sago-grain appearance of the mucous membrane when the history that is usual in these cases has been taken and milking the urethra has produced a glairy, muco-purulent blob of discharge. In any case what seems to be important from the point of view of this review is that it was Bezecny's description of his case of Waelsch urethritis with the endoscopic appearances described by Glingar and the finding that the urethral secretion acted like Frei antigen in cases of lymphogranuloma inguinale which first stimulated our interest in the question of a relationship between the condition hitherto known to one of us as millet-seed or sago-grain urethritis and lymphogranuloma inguinale.

Glingar (I9I4), in his paper on non-gonorrhœal urethritis mentioned above, referred to a description by Grünfeld in I88I of a special form of granular urethritis which he thought in some respects suggested trachoma ("gewissermassen trachomatos"). This form was thought by Glingar, however, to be of the Oberländer rather than the Waelsch type, but Grünfeld's interpretation of his observation is interesting in view of subsequent work, especially that of Lindner, who in I9o9 raised the question of the existence of a genital trachoma. Lindner supported this view with evidence in I9IO and later years until I935, and in I9II and I935 referred to the old doctrine of Arlt that trachoma is derived from blennorrhœa. Also in the same year as Grünfeld recorded the above observation Sattler reported a slight case of conjunctival blennorrhœa in an infant whose mother was not suffering from genital blennorrhœa, the only abnormal sign in the genital region being a slight leucorrhœa. This woman's eye became infected by the conjunctival discharge of the infant and developed trachoma. As the mother lived in a region in which there was no trachoma, and any infection from another source could be excluded, Sattler 
drew the conclusion that there was a close relationship between the infective agents of conjunctival blennorrhœa, leucorrhœa and trachoma.

Kroner, in I884, advanced the hypothesis that nongonococcal conjunctival blennorrhœa of new-born infants was caused by an unknown agent situated in the mother's genital passage. Schmidt-Rimpler, in I890, contesting the commonly expressed view at that time that all blennorrhœa was gonorrhœal, pointed out that in some acute cases of conjunctival blennorrhœa in new-born infants no gonococci could be found, and that the same applied to the genital discharges of the mothers of these infants.

Those who are familiar with millet-seed (? Waelsch) urethritis and with trachoma will probably agree that there is some similarity between the appearances of the mucous membranes in the two conditions, but it seems unnecessary here to discuss closely their likenesses and differences ; our chief concern in this paper is the possibility of an ætiological relationship between them and other conditions mentioned in the title.

A relationship between Waelsch urethritis, inclusion blennorrhœe and trachoma is suggested by the finding mentioned above of inclusion bodies in inclusion blennorrhœa of the conjunctiva, in the uro-genital secretions of the mothers of infants with inclusion blennorrhœa, in trachoma and in Waelsch urethritis. Such inclusion bodies were first discovered in 1907 by Halberstaedter and v. Prowazek in smears of the conjunctival secretion of an orang-outang suffering from experimental trachoma; they called them "Chlamydozoa," and their description of the bodies was broadly as follows.

In preparations stained with Giemsa there were deepblue, " non-homogeneous" or granular bodies lying in the lighter blue epithelial cytoplasm. The bodies were at first small and round or oval, but with age became larger and mulberry-like, the granules becoming separated. Later these bodies were found very close to the. nuclei of the epithelial cells, which they fitted like caps. Afterwards very fine, red-stained granules appeared in the bodies and, increasing in numbers, largely displaced the blue-stained material so that eventually the red-stained matter constituted the greater part of the 


\section{BRITISH JOURNAL OF VENEREAL DISEASES}

inclusion bodies, the blue matter remaining only as islets.

At a later date Lindner (Ig09) referred to the bluestained portions of the inclusion bodies as "initial bodies" and to the red bodies as "trachoma granules" ("Trachom-Körnchen (Trachom-Körperchen)") ; by most authors these " trachoma granules" are generally referred to as " elementary bodies." The term " initial bodies " was adopted by Halberstaedter and v. Prowazek and is now in general use for reference to the blue bodies seen in Giemsa-stained preparations. The size of the elementary body in Giemsa-stained preparations has been stated by Thygeson (I935) to be $0 \cdot 25 \mu$ and that of the initial bodies, $0 \cdot 3 \mu$ to $0 \cdot 8 \mu$ in their greatest diameter.

Other forms than those mentioned above have been described by various workers, notably Thim (I925), who described protozoon-like forms in urethral discharge. Busacca (I933 and I935) was of opinion that trachoma was caused by a Rickettsia, and similar observations were made by Cuénod (I935), Cuénod and Nataf (I935 and I936), and Poleff (I937). The latter workers, though they believed the bodies to be Rickettsia, differed from Busacca in likening them in some respects to those described by ${ }^{\circ}$ Halberstaedter and v. Prowazek. The nature of the bodies is, however, discussed later.

As regards the finding of similar bodies in the other diseases mentioned above, the following observations seem to be pertinent.

In Waelsch urethritis and in non-gonococcal urethritis they have been found by Lindner (I9I0), Siebert (19I0), Scherber (1935), Thygeson and Mengert (1936), and Halberstaedter and v. Prowazek (I9I0) ; in epithelial cells of the urethra of the mother of an infant with non-gonococcal inclusion blennorrhœe by Halberstaedter and v. Prowazek; in material from the genito-urinary tracts of mothers of infants with inclusion blennorrhœa by Thygeson (I934a); in cervical smears of 8 out of Io mothers of such children by Thygeson and Mengert .(I936), who, however, found none in the urethras of these women; and in the urogenital discharges of the parents of an infant with conjunctival blennorrhoa by Heymann; in the latter case the uro-genital discharges of the parents and the conjunctival discharge of the infant contained gonococci as well as inclusion bodies. 
It is of interest to record also that Braley (I938), confirming the finding of Thygeson and Mengert of inclusion bodies in cervical smears of mothers, found that the bodies occurred only in the transitional cells of the cervix.

As regards the nature of the inclusion bodies which have been reported by various workers, some (Halberstaedter and v. Prowazek, Mijaschita, and v. Szily) have discussed the possibility of microscopists being deceived by similar-looking bodies and by artefacts; Halberstaedter and v. Prowazek (I9I0) say that the latter could be produced by incorrect technique in spreading the secretion on the slides, and in the same connection may be mentioned the statement by Thygeson and Mengert (1936) that in smears from the female uro-genital tracts they considered only " elementary body" inclusions to be of diagnostic importance since bacteria in or on cells can simulate " initial bodies." With these qualifications, the above authors agree with the majority of workers that the inclusion bodies have an ætiological relation to the diseases in which they have been found. Grüter (I936 and I938), however, considered them to be only an irritation product of the cell.

Thygeson (I934 a) described a life-cycle of the bodies found in inclusion blennorrhœa. In this an " elementary body" penetrates an epithelial cell and develops into an "initial body," which then divides into multitudes of new " elementary bodies" filling the epithelial cell. The movements of the eyelids burst the cells so affected, scattering the "elementary bodies," which restart the cycle by invading fresh epithelial cells. A similar cycle for the inclusion bodies in trachoma was described by the same author (I934b). Although the bodies found in trachoma are morphologically similar to those in inclusion blennorrhœa, the great probability is that biologically they are different. Thygeson and Richards (I938) believed that the " elementary bodies of trachoma are virus bodies like those of psittacosis and inclusion blennorrhœa."

Contrary to the view of Thygeson, Lindner and also Howard believed that the "initial bodies" were the virus.

Other views on the nature of these bodies may be summarised briefly as follows: That they are involution 
forms of gonococci (Herzog (I9IO)); remnants of hæmoglobinophilic bacteria and gonococci (Williams (I9I4)); other bacteria which have been phagocyted (Bengston (I929) and Spoto (I9I0) ) ; phagocyted bacteria which are not the cause of the disease but carry the virus (McKee (I935)); cell reaction products probably due to activity of invisible infecting agents (Kolle and Hetsch (1934) ); gonococci which have become biologically changed (Fodor (I929)); micro-organisms which are either parasites or germs of mixed infections (Flemming (I910a) ) ; Rickettsia (Cuénod and Nataf (I937), Cuénod, Nataf and Loukitch (1938), Poleff (I937) and Busacca (I933 and I935) ). Each of these views has been opposed, but to discuss them would lead too far from the object of this review. In regard to the view that the bodies are Rickettsia, Thygeson (1938) did not think those which he saw in the preparations of Cuénod and Nataf, and of Busacca, were Rickettsia, but in all probability cell granules and cytoplasmic débris. Braley (I939) thought them to be "stained mitochondria and keratin granules rather than Rickettsias." Foley and Parrot (I937 and I939) also considered that the bodies described by Cuénod and Nataf were artefacts, though they believed that the inclusion bodies of Halberstaedter and v. Prowazek were Rickettsia and called them "Rickettsia trachomatis (Chlamydozoon trachomatis)" ; the reasons for regarding these bodies as Rickettsia had been stated by Foley and Parrot in 1937. As regards their position in nature, Thygeson and Richards (1938) considered that the "virus of trachoma, with the virus of inclusion blennorrhœa and psittacosis, appear to form a group transitional between Rickettsiæ and the typical viruses." In this connection we may mention that Weil-Felix serological reaction has been found to be positive in a considerable number of cases of trachoma (Derkač (I937 and 1938), Djourichitch and Loukitch (1938), Poleff (I938) and Poštić (1938)), which might suggest a Rickettsia origin and that it would be interesting to test the blood similarly in cases of inclusion blennorrhœe, Waelsch urethritis and lymphogranuloma inguinale, but recently some observations by Weigl (I939) have raised a doubt of the specificity of the Weil-Felix reaction for diseases due to Rickettsia. According to his experience the $\mathrm{X}$-titre oscillates also in healthy persons, and exceptionally in these also high 
titres may occur. Also he found that normally high titres could increase in strength in consequence of various diseases and then decrease, as has been described in trachoma. Weigl also showed that Cuénod and Nataf had been deceived by the presence in their lice of a harmless parasite. This had been the opinion also of Trapezontzeva (I938), who claimed that the presence of Rickettsia in lice infected with trachomatous material is incidental and can be avoided by care in technique ; they are non-pathogenic parasites of lice.

Evidence of the ætiological relationship of inclusion bodies found in inclusion blennorrhœa, in trachoma and possibly Waelsch urethritis to these diseases is afforded also by inoculations, both natural and experimental.

It seems most convenient to discuss this work under the headings of trachoma, inclusion blennorrhœa and urethritis.

\section{Inoculation with Trachomatous Material}

With material from the conjunctiva in trachoma many authors have reported successful inoculation of the eyes of monkeys.

In the earlier part of this review we mentioned that Halberstaedter and v. Prowazek had found inclusion bodies in an orang-outang suffering from experimental trachoma. The finding of inclusion bodies in conjunctival smears and scrapings after inoculation of monkeys, sometimes with fresh trachomatous discharge, sometimes with filtrates of this, has been reported by Bertarelli and Cecchetto (I908), Herford (I909), di Santo (I909), Flemming (I9Io b), Heymann (I9I0), Botteri (I9I2) and Stewart (I935). A number of authors, including Hess and Römer (I906), Fermi and Repetto (I907), Löhlein (I9I2), Nicolle, Blaizot and Cuénod (I9I2), Olitsky, Knuth and Tyler (I93I), Julianelle, Morris and Harrison (I934), Thygeson and Proctor (I935) and Thygeson and Richards (I938), have reported successful inoculations, with trachomatous discharge and with filtrate, on the strength of the development of trachomatous changes in the inoculated eyes. The above-mentioned reports contain only scanty references to the finding of inclusion bodies, and Julianelle and Harrison (I933) even stated their belief that it was impossible to correlate successful inoculation with the presence of inclusion bodies; in the 


\section{BRITISH JOURNAL OF VENEREAL DISEASES}

following year (I934) they said "the infectivity of a given tissue does not appear to be related to the presence or absence of epithelial inclusions in the tissue used for inoculation." They added, "Similarly repeated examinations of infected monkeys failed to reveal the presence of inclusions." It must be admitted that in the conjunctivitis of monkeys resulting from trachomatous inoculation, inclusion bodies have not been reported often, but Julianelle and Harrison seem to go too far when they say " it is difficult therefore to reconcile these observations with the concept that 'inclusions' are intimately involved in the ætiology of trachoma." Evidence against the opinion of Julianelle and Harrison is afforded by the result of inoculation with trachomatous material of a volunteer which was carried out by Thygeson, .Proctor and Richards (I935). The inoculum was a bacterium-free filtrate in the sediment of which, after high-speed centrifugation, elementary bodies were found, and in the trachomatous conjunctiva resulting from the inoculation both inclusion and free elementary bodies were seen. A very large scale investigation by Shimizu (r937) also supported the evidence as to the ætiological relationship of inclusion bodies to trachoma. Shimizu inoculated 26 cases (47 eyes) with trachomatous material and examined no less than I,500 conjunctival smears before and after the inoculation. Whereas no inclusion bodies were seen beforehand, they were found in all but four eyes after it. The exceptions were four spontaneously infected eyes examined only four times. Although the inoculation material appeared to contain no inclusion bodies, these were most abundant in the inoculated conjunctivas twenty-two days after the inoculation. In this connection also may be mentioned an experiment by Greeff (I909), who inoculated a volunteer with trachomatous material containing inclusions, and these bodies were subsequently found in the conjunctival smears of the inoculated patient.

\section{INOCULATION EXPERIMENTS IN INCLUSION BlenNoRrhea OF THE Eye}

Successful inoculations on similar lines to those in trachoma have been carried out on monkeys with material from inclusion blennorrhœa by Lindner (I909 b) ; Fritsch,

$$
246
$$


Hofstätter and Lindner (I9Io); Flemming (I9Io b) ; Heymann (I9I0); Botteri (I9I2); Löhlein (I9I2); Thygeson (I934 a); Tilden and Gifford (I936) ; Julianelle (1937); and Julianelle, Harrison and Lange (r938). Success was judged by the appearance of the conjunctiva, but most of the above authors reported finding inclusions in the inoculated conjunctivas. Also Botteri ; Tilden and Gifford; and Julianelle, Harrison and Lange reported successful inoculation with filtrates of discharge from inclusion conjunctivitis.

Inclusion conjunctivitis has also been experimentally conveyed to man by Wolfrum (I9IO-II), 2 positive results; Gebb (I9I4), 8 positive results, with inclusions found in 6; Taboriski (I930), self-inoculation, inclusions found; Thygeson (I934 a), 2 positive results, abundant inclusions in one. Also Thygeson (I934 a), and Thygeson and Mengert (1936) in cases with unilateral inclusion conjunctivitis transmitted the disease to the other eye. These authors tried to imitate the natural mode of infection by inoculating with scrapings from the conjunctiva of an infant with inclusion blennorrhœa the vaginal vaults (hitherto free of inclusion bodies) of 4 women in the last month of pregnancy. No symptoms followed, and the women's infants did not develop conjunctivitis. Possibly here the reason for the failure was that the adult vagina is an unfavourable medium, as was suggested by the authors and by the work of Braley. In a second experiment Thygeson and Mengert inoculated with scrapings from the eye of an infant with inclusion blennorrhœa the cervical canals of 2 women just prior to the onset of labour; no changes were noted in the cervices, and no conjunctivitis occurred in the new-born infants. One of the mothers was subsequently tested, and smears of the cervical secretion showed numerous inclusions and free elementary bodies. A possible explanation of this failure to transmit the disease to the infant may be that the interval between inoculation and birth was too short.

Experimental transmission of inclusion blennorrhœa to men with filtrates of discharges from cases of this disease have been reported by Gebb (I9I4), I case with typical clinical appearances; Thygeson (I934 a), I volunteer and I self-inoculation, both resulting in clinical signs, with inclusions. 


\section{BRITISH JOURNAL OF VENEREAL DISEASES}

Besides these cases accidental infections of human beings with inclusion blennorrhœa have been reported by Lindner (I9II). This author described 4 cases, the first an infection from child to mother; the second, one from child to sister; the third, one from urethritis to eye of same patient ; and the fourth, one in which a surgeon is stated to have acquired " typical trachoma " as a result of infection during an abdominal operation. Julianelle, Harrison and Lange (I938) expressed some scepticism on this last case. Noguchi and Cohen (I9II) reported I case, from child to mother, inclusions being found ; and Thygeson (I934 a), one from child to mother. Marchesani (I936) reported the development of a trachoma-like affection of the eye of a woman doctor who received a splash of amniotic fluid in the eye; abundant inclusions were found in the infected eye. Thygeson and Mengert (1936) reported infection of a gynæcologist whose eye received a spurt of blood during curettage ; inclusions were found in the infected eye. Lastly, Julianelle, Harrison and Lange (1938) reported infection of a nurse by a child; inclusion bodies were present in the child's eye, and the nurse developed typical follicular conjunctivitis, inclusion bodies being found in the conjunctival scrapings. Julianelle, Harrison and Lange tried to repeat the successful inoculation reported by Lindner of the vagina of a baboon with material from inclusion blennorrhœa, but failed with five monkeys.

Inclusion conjunctivitis has been successfully treated with sulphanilamide by Thygeson (I939), who noted disappearance of inclusion bodies with clinical improvement. Richards, Forster and Thygeson (I939) also treated with sulphanilamide children suffering from trachoma. They noted that during treatment inclusion bodies typical of trachoma which were previously present disappeared, and the pooled conjunctival scrapings taken on the twenty-ninth day failed to infect baboons.

Thygeson and Mengert (I936), like Bahn (I927), believe that "swimming-bath conjunctivitis" is also due to inclusion bodies, probably derived from the genitourinary tract. They suggest that, when protected in epithelial cells floating in the swimming-bath water, the inclusion bodies can resist chlorination. Other workers share the belief that "swimming-bath conjunctivitis" is due to inclusion bodies, and it has been suggested 
that "swimming-bath conjunctivitis" and inclusion blennorrhœa are identical.

INOCULATION WITH MATERIAL FROM THE URO-GENITAL CANALS

Fritsch, Hofstätter and Lindner (Igro) inoculated the conjunctiva of a baboon with urethral discharge from a case of non-gonococcal urethritis which they considered to be of the Waelsch type. Inclusion bodies were present in the urethral discharge and subsequently were found in conjunctival secretions of the baboon, whose conjunctiva became granular. The same authors successfully inoculated a macaque with genital discharge (containing no inclusions) from the mother of an infant with inclusion conjunctivitis. The animal developed a granular conjunctivitis in the secretion of which only free initial forms were seen. A baboon inoculated with the same, genital, material developed a severe trachoma-like conjunctivitis containing inclusion bodies. Heyman (I9I0) inoculated successfully the conjunctivas of long-tailed monkeys with genital discharge of three mothers of infants with inclusion blennorrhœa; in I case the genital secretion contained gonococci and inclusion bodies, but in the other 2 neither were found. The monkeys developed conjunctivitis, and inclusions were found in all of them. In the case of the two monkeys inoculated with material showing neither gonococci nor inclusions the monkeys' vaginas were also inoculated with the same material; one subsequently showed inclusion bodies in the vagina. Heymann also inoculated two long-tailed monkeys and two baboons with urethral discharge from three fathers and one mother of infants with inclusion blennorrhœa. In three cases the inoculum showed only gonococci and in one both gonococci and inclusions. All four animals developed conjunctival changes in which inclusion bodies were found. Thygeson also successfully inoculated the eyes of sphinx baboons with vaginal secretions (containing inclusion bodies) of three mothers of infants with conjunctivitis.

As regards a connection between Waelsch urethritis and conjunctivitis in man, Waelsch saw conjunctivitis of both eyes in a case of Waelsch urethritis, and relapse of urethritis coincided with relapse of the conjunctivitis. 


\section{BRITISH JOURNAL OF VENEREAL DISEASES}

Lindner (IgIo) reported the case of a patient of the better class with early trachoma of the right eye containing inclusion bodies, who had also a urethritis which appeared to be of the Waelsch type.

\section{Cultivation Experiments}

Noguchi and Cohen (IgII) reported that they had cultivated the elementary and initial bodies of trachoma in a rabbit's kidney ascitic fluid medium, but this work has not been confirmed by others. Poleff (I937) claimed to have cultivated Rickettsia-like bodies from the follicles in trachoma and from pannus material by the tissueculture method, but the experiments of Julianelle and Harrison (I937) failed to afford evidence that the agent of trachoma is cultivable by the tissue-culture method. In a later paper (I938) they mentioned that Thygeson (personal communication) had also failed to cultivate the virus by this method. Thygeson and Mengert (1936), as a result of a careful study of the paper by Noguchi and Cohen, stated their belief that the elementary and initial bodies of trachoma had not been cultivated. Braley (I938) failed to cultivate trachoma bodies on living epithelium.

\section{INCLUSIONS IN LYMPHOGRANULOMA INGUINALE}

The evidence so far discussed suggests that the inclusion bodies found in some forms of non-gonococcal urethritis, trachoma and inclusion blennorrhœa may be specific organisms responsible for these conditions. Granules of somewhat similar appearance have been found in lymphogranuloma inguinale (L.i.) and are now generally believed to be the cause of this disease.

Findlay (I933) mentioned that the first suggestions that the virus of this disease is visible emanated from Gamna in 1923 and Favre in 1924. He pointed out, however, that the Gamna-Favre bodies gave a positive reaction with thymonucleic acid and were very similar to bodies described by Flemming in I885 in the cytoplasm of cells from normal lymph glands. Smaller granules were, however, reported by Gay-Prieto in I927 and by Findlay who considered the question of their being the virus but was not then able to arrive at a final conclusion on this point; he said "Whether these granules 
actually represent the virus cannot as yet be determined." In I935 the ætiological relationship to L.i. of certain small granules found in material from men and animals infected with this disease was suggested by Miyagawa and colleagues.

The latter authors found certain " granulo-corpuscles " in the cells of lymph glands from 20 cases of L.i. and in the brain, cord, testes, glands and peritoneal fluid of 68 monkeys which had been infected with the virus.

In the English summary of their first report on L.i. the bodies were described as spherical, $0 \cdot 3 \mu$ in diameter in the stained condition and appearing a dark reddish colour in specimens stained by Giemsa. Under decolorisation by acetone they retained their colour or became bluish, while neutrophilic granules in leucocytes and azurophilic ones in histiocytes and lymphocytes became very pale.* They were not stained by the Feulgen method or by Gram.

As regards their distribution, they were commonly free and strewn throughout the cytoplasm but sometimes were double or in chains, and often in aggregations like bunches of grapes. The numbers varied in different sites, being very abundant in some parts of the gland or brain but scanty in others. The summary ended with a statement of the authors' view that " these granulo-corpuscles are probably worthy enough to be regarded as the virus of this disease."

In a second report (I935 b) Miyagawa and colleagues reported finding the granulo-corpuscles in infected mice and said they were easily distinguishable from the granules seen by Toyama, Hasegawa and Ichikawa (I935) in lymph glands affected with Hodgkin's disease, with chancroid or with syphilis. They had failed to find similar bodies in normal monkeys, or in those infected with many diseases other than L.i. They repeated their description of the corpuscles and stated that they occurred chiefly in histiocytes but sometimes in glia and other cells. In some cells they were scattered but in others filled the cytoplasm. In a third report (I935 c) they showed that

* In this connection it may be of interest to note that Thygeson (1934 a) mentioned that elementary bodies found in inclusion blenorrhœa " are readily differentiated from the neutrophilic granules, which they somewhat resemble in size, by the fact that they are alcohol-fast." 
the virus could pass filters with pores larger than $0 \cdot 33 \mu$ but not those with pores less than $0 \cdot 24 \mu$; they demonstrated the bodies on filters with pores of $0 \cdot 24 \mu$. In contrast to the failure by various workers to cultivate trachoma bodies, Miyagawa and colleagues in their fourth report (I935 d) described culture of the virus of L.i. on chorio-allantoic membrane of chicken embryos. The culture was carried through five generations, during which the organisms remained morphologically typical and were virulent for mice. The fifth report (I935 e) described experiments on the effect of cold and heat on virulence. The sixth (I936 a) described successful inoculation of various rodents and the finding of granulocorpuscles in the resulting lesions. The seventh (I936 b) described cultivation of the granulo-corpuscles by the tissue culture method and successful inoculation of mice with subcultures, and the eighth (I936 c) reported failure to cultivate the virus by Tamura's method (I934 and I935), which made use of Maitland, Laing and Lyth's medium for growth of vaccinia. Tamura had, however, produced evidence that his subcultures were virulent for guinea-pigs and acted as antigen in Frei tests.

The work of Miyagawa and colleagues has been confirmed by a number of other workers, amongst whom may be cited the following. Mauro (I937) used the FontanaTribondeau silver method of staining and also Victoria blue, as recommended by Herzberg and Koblmüller, and gave reasons for believing the bodies to be Rickettsia. This was also the view of Caminopetros (I938), who found them in the reticulo-endothelial cells. Ishimitsu (I936 and 1937) described a method of staining the bodies in sections and reported finding them in the histiocytes, the walls of the lateral ventricles, the meninges and the vessels of infected mice and in histiocytes and plasmocytes of buboes of 8 patients suffering from L.i. The findings of Ishimitsu have been disputed by Nauck and Malamos on the grounds that the bodies described were too large.

Satani and Sano (I936) stated that by selecting material containing Miyagawa corpuscles, one could more certainly ensure successful inoculation in refractory animals. The intensity of the disease process in the tissues seemed to be dependent on their richness in Miyagawa corpuscles. Tasaki (1936), Nauck and Malamos (r937) and Schoen (1938) have also published accounts of the bodies 

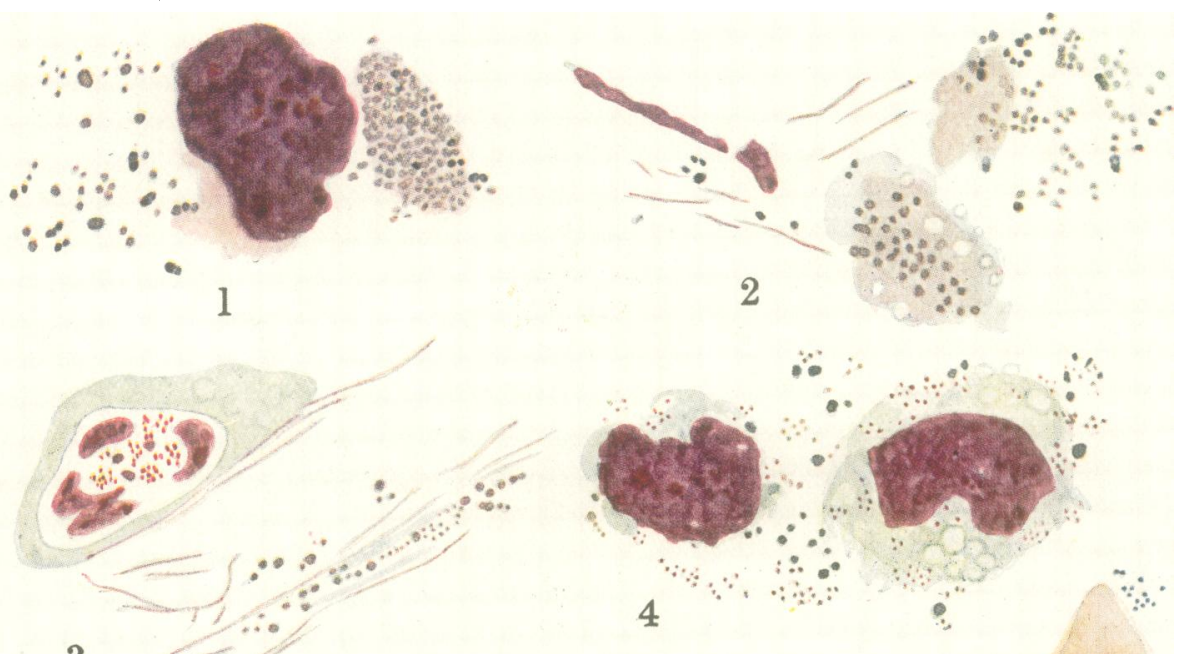

3

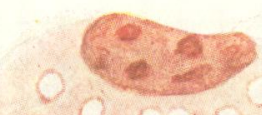

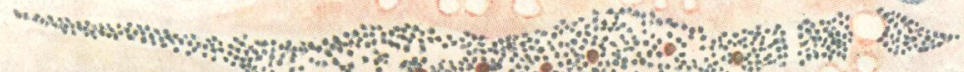
H.

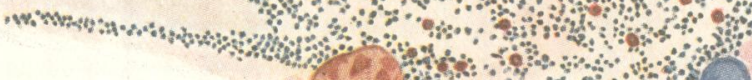

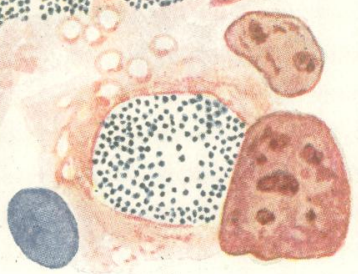

6
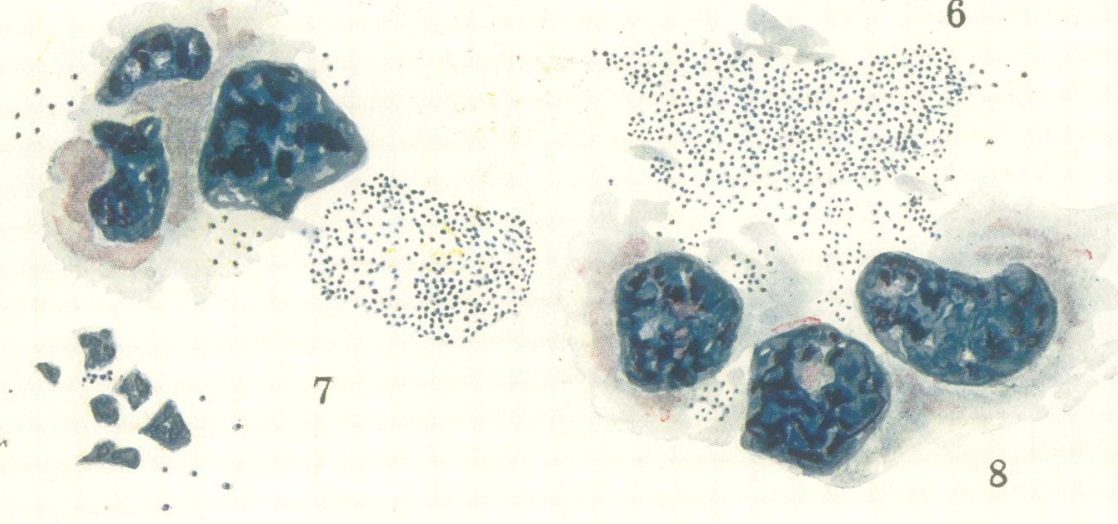

G.M.F.

VIRUS OF LYMPHOGRANULOMA INGUINALE

( 
which agree substantially with those of Miyagawa and colleagues.

As regards their size, filtration experiments have shown them to be smaller than the $0 \cdot 3 \mu$ estimated by Miyagawa and colleagues in their stained specimens. Broom and Findlay (I936) estimated them to be from $0 \cdot 125 \mu$ to $0 \cdot I 75 \mu$, and Findlay and colleagues (I938) quoted other estimates ranging from $0 \cdot I \mu$ to $0 \cdot 2 \mu$.

Successful cultivation by Miyagawa et al. and by Tamura has been mentioned. Besides these, Malamos (I937) reported culture not only on chorio-allantoic membrane but also on rabbit's cornea, and in 1938 described culture on rabbit's corneal epithelium according to the method of Nauck and colleagues (I937) which permitted microscopical observation of the development of the bodies in the culture medium. Nauck, referring to the work of Malamos, reported in I937 that, in collaboration with Marschall, he had been successful in cultivating another strain of the L.i. virus by this method. His cultures had been proved to be virulent for mice.

A developmental cycle has been suggested by Findlay, Mackenzie and MacCallum (I938) to whom and the Council of the Royal Society of Tropical Medicine we are indebted for permission to reproduce the plate illustrating the life cycle. They worked with three strains of the organisms, and as a result of examinations of the brains of mice at intervals following inoculation they offered the following tentative account of the process.

\footnotetext{
" On intracerebral inoculation the elementary bodies for some hours are so few in number that in smear preparations they remain unseen. Then the small forms swell up and appear as large forms, which divide to form other large forms so that a compact mass is produced. This morula-like mass is probably intracellular, but after a time some of the large forms break off from the compact masses, enter the cytoplasm of other cells and begin to give rise to numerous smaller forms so that small and large forms are seen together. Eventually the large forms disappear, their place being taken by masses of small forms. Whether these small forms themselves actually divide is still uncertain though undoubtedly many diplococcal and chain forms are noticeable. If sufficiently numerous in the cytoplasm the small elementary bodies form collections within cyst-like spaces bounded by definite limiting membranes; these eventually rupture as emphasised by Schoen (I938) and the elementary bodies are liberated
} 


\section{BRITISH JOURNAL OF VENEREAL DISEASES}

from the cell cytoplasm in a condition capable of infecting fresh cells."

Readers may perhaps be interested to compare this description with that by Thygeson of the life cycle of the bodies found in inclusion blennorhœa and in trachoma which was mentioned above.

\section{Allergic Skin Reactions}

It is unnecessary here to remind readers of the Frei reaction which is produced in the skin of those who have been infected with L.i. by intracutaneous injection of material containing the killed virus. So far as we know, this skin reaction had not been evoked in L.i. subjects by material other than that containing L.i. virus and material from Parinaud conjunctivitis until, as mentioned by Ross in his paper in the April number of this Journal, it was shown by Frei, Wiese and Klestadt (I932) and by Bezecny (I934) that it would result from intracutaneous injection of urethral discharge from patients with Waelsch urethritis. In the case described by Frei, Wiese and Klestadt the question of the urethritis being due to lymphogranuloma inguinale was considered because of some swelling of inguinal glands, but a diagnosis of Waelsch urethritis was finally made because of the later behaviour. The urethroscope does not seem to have revealed any " millet-seed" condition. In Bezecny's case, as already mentioned, the clinical data were characteristic of Waelsch urethritis and the urethroscopic appearances were those described by Glingar. Allergic skin reactions by patients with Waelsch urethritis to Frei (L.i.) antigen have been reported by Bezecny (I934), by Fahlbusch and Zierl (I937) and by Ross (I939).

Bezecny was inclined to think that the explanation of these cross allergies lay in a relationship between Waelsch urethritis and L.i., though he considered that the two diseases are not due to the same cause.

Kalz (I933) described 3 cases of urethritis, Waelsch type, the discharge from which when suitably prepared acted like Frei antigen in cases of L.i. The diagnosis of Waelsch urethritis in these cases rested only on the correspondence of the clinical signs with those described by Waelsch, the urethroscope showing nothing more than a slight inflammation. Antigens made from other forms of 
urethritis failed. Kalz suggested that Waelsch urethritis was due to a germ similar to that responsible for L.i.

Bizzozero and Midana (I938) as a result of obtaining skin reactions with Frei antigen in 15 out of 18 cases of "Waelsch urethritis," concluded that the majority of cases of Waelsch urethritis are L.i.

Polak (I933) described 3 cases in which a non-gonococcal urethritis preceded the bubo in L.i., and both it and the bubo were cleared up by the same remedy, neo-stibosan. He suggested that apparently non-specific Frei reactions might be explained by the presence of a latent L.i. in which the disease was present as a very mild urethritis and a deep-seated adenopathy.

\section{Conjunctivitis CAUSEd By L.I. Virus}

That the virus of L.i. can cause conjunctivitis is shown in experiments by Cottini (I938), who found that mice infected intracerebrally with L.i. developed conjunctivitis in histological sections from which the virus was demonstrated.

Several other workers have specially noted conjunctivitis in animals after intracerebral inoculation with L.i. virus.

Ichijô (I937 a) found in 3 cases with eye symptoms clinically identical with Parinaud conjunctivitis, I having tularæmia and the other 2, L.i., that the conjunctival discharge of the 2 L.i. cases acted as Frei antigen in L.i. cases. As a control of this finding he reported later (I937 b) that in some L.i. cases with conjunctivitis which appears from his German summary not to have been due to this disease the increased conjunctival secretion resulting from artificial irritation did not produce any reaction in the skins of 9 out of Io L.i. cases, the reaction in the tenth case being doubtful. In this later paper he reported also successful inoculation of mice with discharge from the conjunctivas in L.i. cases with conjunctivitis of the Parinaud type.

\section{CONCLUSION}

We are conscious that the above review, which was written for the interest of venereologists, lacks much information which is necessary to prove conclusively a 
relationship between the diseases discussed. To fill the gaps much more research is necessary, but if this summary of literature on the subject should stimulate some worker to undertake a decisive experimental work in this field, our labour in compiling it will be repaid.

A point which seems to require elucidation is whether or not Waelsch urethritis as described by Waelsch, the "Waelsch urethritis" of Glingar and the condition which we know here as " sago-grain " or " millet-seed" urethritis are identical, and if not, how they are related to one another.

It appears important in this connection to search the discharge in each of these conditions for inclusion bodies and to inoculate with the same material the conjunctivas of monkeys. Also, their relations to one another and to lymphogranuloma inguinale would probably be made clearer by intracerebral inoculations of mice and other susceptible animals.

Another line of research which appears to be indicated is to investigate further the question of allergic skin reactions in these cases. We would suggest that this should be done in every case of urethritis of any of the kinds discussed in this review.

\section{REFERENCES}

BAHN, C. (I927) New Orl. med. surg. J., 79, 586.

Bengston, I. A. (I929) Amer. J. Ophthal., 12, 637.

Bertarelli, E. \& Cecchetto, E. (I908) Zbl. Bakt. I Abt. Orig., 47, 432. BEZECNY, R. (I934) Med. Klinik, 30, I2I.

Bizzozero, E. \& Midana, A. (I938) Annal. Derm. Syph. Paris, 9, 849. Botteri, A. (I9r2) Klin. Mbl. Augenheilk., 50, i, 653.

Braley, A. E. (I938) Amer. J. Ophthal., 21, 203 ; (I939) Arch. Ophthal., 21, 735 .

Broom, J. C. \& Findlay, G. M. (I936) Brit. J. exp. Path., 17, I35.

Busacca, A. (I933) I4th Int. Cong. Madrid. (Abstract Klin. Mbl. Augenheilk., 91, 278) ; (1935) Graef's Arch. Ophthal., 133, $4 \mathrm{I}$.

Caminopetros, J. (I938) Bull. Acad. Med. Paris, 119, 697.

Cottini, G. B. (I938) Boll. Soc. med-chir. Catania, 6, 30I (Abstr. Zbl. Haut u. Geschl. Kr I938, 60, 701).

Cú́nod, A. (I935) Arch. d'Ophtal., 52, I45.

Cut́nod, A. \& NATAF, R. (I935) ibid. 52, 573 ; (I936) ibid. 53, 218 ; (1937) Arch. Inst. Pasteur Tunis, 26, I.

Cuknod, A., Nataf, R. \& Loukitch, G. (r938) Bull. Soc. exot. Paris,

31, 22. Ref. Arch. Schiffs. u. Tropenhyg. (1939) 43, 44.

Derkač, V. (I937) Klin. Mbl. Augenheilk., 99, 596; (1938) ibid. 


\section{NON-GONOCOCCAL URETHRITIS, ETC.}

Djourichitch, M. \& Loukitch, G. (I938) C.R. Soc. Biol. Paris, 128, 832 .

Fahlbusch, W. \& ZieRL, R. (I937) Derm. Wschr., 105, II77.

Favre, M. (I924) $\mathrm{Pr}$. Méd., 32, 65I (ref. Findlay).

Fermi, C. \& Repetto, R. (I907) Berl. klin. Wschr., 44, II97.

Findlay, G. M. (I933) Trans. R. Soc. trop. Med. Hyg., 27, 35.

Findlay, G. M., Mackenzie, R. D. \& MacCallum, F. O. (I938) ibid.

32, 183 .

Flemming, (igio a) Berl. klin. Wschr., 47, 796 ; (igio b) Arch.

Fodor, G. (I929) Klin. Mbl. Augenheilk., 83, 264.

Augenheilk., 66, 63.

Folet, H. \& Parrot, L. (I937) C.R. Soc. Biol. Paris, 124, 230 ; (I939) Arch. d'Ophtal., 3, 230.

Frei, W., Wiese, L. \& Klestadt, L. F. (I932) Klin. Wschr.,

11, 2 I I 4 .

Fritsch, H., Hofstätter, A. \& Lindner, K. (igio) Graefe's Arch. Ophthal., 76, 547 .

FrüHWALD, R., Handbuch der Haut-u. Geschlechtskr. von J. Jadassohn,

Gamna, C. (Ig23) Arch. Sci. Med., 46, 3I (ref. Findlay).

Berlin I927, 21, 478 .

Gay-Prieto, J. A. (I927) Acta dermosifilo Madr., 20, I22 (ref. Findlay).

GeBb, H. (I9I4) $Z$. Augenheilk., 31, 475.

GlingaR, A. (I9I4) Wien. med. Wschr., 64, 59I ; (I932) Z. Urol., 26, 246.

Greeff, R. (Igog) Klin. Jahrb., 21, 453.

Grüter, W. (I936) Ber. dtsch. ophthal. Ges., 51, 277 ; (I937) Brit. J. Ophthal., 22, 300.

Halberstaedter, L. \& v. Prowazek, S. (I907) Arb. Gesundh. Amt Berl., 26, I ; (г910) Berl. klin. Wschr., 47, 66r.

Herford, E. (Igog) Klin. Mbl. Augenheilk., 47, 225.

Herzberg, K. \& Koblmüller, L. O. (I937) Klin. Wschr., 16, II73.

Herzog, H. (r9io) Dtsch. med. Wschr., 36, Io76, I535, I945.

Hess, C. \& Römer, P. (I906) Arch. Augenheilk., 55, I.

Heymann, Br. (I9Io) Berl. klin. Wschr., 47, 663. Handbuch d. path. Mikroorg., Kolle, W. \& Wassermann, A. v., Jena, I9I3, 8, 623 .

Howard, H. (I924) Amer. J. Ophthal., 7, 909.

IchiJô, M. (I937 a) Act. Soc. Ophthal. Jap., 41, i, 5I ; (I937 b) ibid. 41, ii, Io8 (German summaries).

Ichikawa, T. (I935) Jap. J. Derm. Urol., 37. German summary 77.

Ishimitsu, K. (I936) Jap. J. exp. Med., 14, 39I ; (I937) ibid. 15, I85.

Julianelle, L. A. (I937) Proc. Soc. exp. Biol. N.Y., 36, 6I7.

Julianelle, L. A. \& Harrison, R. W. (I933) Amer. J. Ophthal., 16,

857; (I934) ibid. 17, I035; (I937) ibid. 20, 360 ; (I938) ibid. 21, 529.

Julianelle, L. A., Harrison, R. W. \& Lange, A. C. (I938) Amer. J. Ophthal., 21, II $37 \&$ I230.

Julianelle, L. A., Morris, M. C. \& Harrison, R. W. (I937) Amer. J.

KALz, F. L. (1933) Med. Klinik, 29, ii, I679.

Ophthal., 20, 890.

Kolle, W. \& Hetsch, H. "Experimentelle Bakteriologie u. InfekKRONER (I884) Zbl. Gynäk., 8, 643. tionskrankheiten," Berlin, I934. 


\section{BRITISH JOURNAL OF VENEREAL DISEASES}

LINDNER, K. (IgO9 a) Wien. klin. Wschr., 22, I742 ; (IgO9 b) ibid. 22, I555 \& I659; (I9I0) ibid. 23, 283; (I9II) Graefe's Arch. Ophthal., 78, 345; (I92I) Wien. med. Wschr., 71, 1067; (1925) ibid. r5, 2488; (1935) Wien. klin. Wschr., 48, I487.

Löhlein, W. (I9I2) Arch. Augenheilk., 70, 392.

McKee, S. H. (I935) Amer. J. Ophthal., 18, 36.

Maitland, H. B., Laing, A. W., \& LyTh, R. (I930) Brit. J. exp. Path., 13, 90 .

Malamos, B. (I937) Zbl. Bakt. I Abt. Orig., 140, Beiheft I64; (I938)

Marchesani (I936) Z. Augenheilk., 88, i64. ibid. 143, I.

Mauro, E. (I937) Boll. Sez. ital. Soc. int. Microbiol., 9, 339.

Mijaschita, S. (I908) Klin. Mbl. Augenheilk., 46, ii, 626.

Miyagawa, Y., Mitamura, T., IshiI, N. \& Okanishi, J. (I936 a) Jap. J. exp. Med., 14, I97.

Miyagawa, Y., Mitamura, T., Yaoi, H., Ishil, N., Nakajima, H., Okanishi, J., Watanabe, S. \& Sato, K. (I935 a) ibid. 13, $\mathrm{I}$.

Miyagawa, Y., Mitamura, T., Yaoi, H., Ishit, N. \& Okanishi, J. (I935 b) ibid. 13, 33I ; (I935 c) ibid. 13, 723 ; (I935 d) ibid. 13, 733 ; (I935 e) ibid. 13, 739.

Miyagawa, Y., Mitamura, T., YaOI, H., IshiI, N., OKanishi, J., Goto, T. \& Shimizu, S. (I936 b) ibid. 14, 207.

Miyagawa, Y., Mitamura, T., Yaor, H., Ishi, N., OKanishi, J., KanazaWA, K. \& Yamada, M. (I936 c) ibid. 14, $22 \mathrm{I}$.

Nauck, E. (1937) Arch. Schiffs. u. Tropenhyg., 41, 748.

Nauck, E. \& Malamos, B. (I937) ibid. 41, 537.

Nicolle, C., Blaizot, L. \& Cuénod, A. (Igi2) C.R. Acad. Sci.,

155, 24I.

Noguchi, H. \& Cohen, M. (I9II) Arch. Ophthal., 40, I ; (Igr4) ibid.

43, II7.

Olitsky, P. K., Knuth, R. E. \& Tyler, J. R. (I93i) J. exp. Med.,

Polak, H. J. (I933) Derm. Wschr., 96, 233.

54,557 .

Poleff, L. (I937) Klin. Mbl. Augenheilk., 99, 584; (I938) ibid.

Poštić, Sv. (1938) Klin. Mbl. Augenheilk., 101, 34I.

101, 243 .

Richards, P., Forster, W. G. \& Thygeson, P. H. (I939) Arch.

Ross, A. O. (I939) Brit. J. vener. Dis., 15, I47.

Ophthal., 21, 578.

SANTo, C. DI (I909) Klin. Jahrbuch, 21, 49I.

Satani, Y. \& Sano, J. (I936) Jap. J. exp. Med., 14, 523.

Sattler (I88I) Klin. Mbl. A ugenheilk., I9 Jahrg. Beilage und Berichte, p. I8.

Scherber, G. (I935) “Haut-u-Geschlechtkrankh." von Arzt \& Zieler, Berlin, I935, 5, 640 .

Schmidt-Rimpler, H. (I89o) Dtsch. med. Wschr., 16, 682.

Schoen, R. (1938) C.R. Soc. Biol. Paris, 127, 677.

Shimizu, Mitsuta (I937) Arch. Soc. Ophthal. Jap., 41, ii, Io6.

Siebert, W. (I9Io) Münch. med. Wschr., 57, i, I279.

Sрото (Igro) Sulla etiologia del Tracoma. Tesi di libera dorenza, Palermo. 
Stewart, F. H. (I935) Brit. med. J., 1, I26I ; (I939) Brit. J. Ophthal.,

SzILy, A. v. (I9II) Klin. Mbl. Augenheilk., 49, ii, 256.

33, 373 .

TABoriski, J. (I930) Graefe's Arch. Ophthal., 124, 455.

Tamura, J. T. (I934) J. Amer. Med. Ass., 103, 408; (I935) J. Lab.

TASAKI, K. (I936) J. orient. Med., 24, English summary, 5 I.

clin. Med., 20, 393.

Thiм, J. R. (I925) Z. Hyg. Infektkr., 104, 358.

Thygeson, Ph. (I934 a) Amer. J. Ophthal., 17, Ior9; (I934 b) Arch. Ophthal., 12, 307; (I935) Amer. J. Ophthal., 17, IoI9; (1938) Arch. Ophthal., 20, I6 ; (1939) ibid. 22, I79.

Thygeson, Ph. \& Mengert, W. F. (I936) Arch. Ophthal., 15, 377.

Thygeson, Ph. \& Proctor, Fr. J. (I935) ibid. 13, IoI8.

Thygeson, Ph., Proctor, Fr. J. \& Richards, P. (I935) Amer. J. Ophthal., 18, 8II.

Thygeson, Ph. \& Richards, P. (I938) Arch. Ophthal., 20, 569.

Tilden, E. B. \& Gifford, S. R. (I936) Arch. Ophthal., 16, 5I.

Toyama, I., Hasegawa, M. \& Ichikawa, T. (I935) Jap. J. Derm. Urol., 37, German summary, 77.

Trapezontzeva, E. E. (I938) Abstract Amer. J. Ophthal., 22, 2 I8.

WAELSCH, L. (IgOI) Prag. med. Wschr., 26 (ref. Waelsch I904); (I904) Arch. Derm. Syph. Wien. 10, I03; (I9I6) ibid. 123, 1089.

WEIGL, R. (I939) Zbl. Bakt. I. Orig., 143, 29 I.

Williams, A. W. (I9I4) J. Inf. Dis., XIV, 26r.

Wolfrum, M. (I9IO-II) Ophthal. Ges. Heidelberg, 36, 207 ; quoted by Lumbroso, U. (I934) Arch. Inst. Pasteur Tunis, 23, 60 . 